\title{
Effect of Growth Opportunity, Corporate Tax, and Profitability toward Value of Firm through Capital Structure (Listed Manufacturing Companies of Indonesia)
}

\author{
Amarudin $^{\mathrm{a}}$, M. Adam ${ }^{\mathrm{b}}$, U. Hamdan' ${ }^{\mathrm{c}}$, A. Hanafi ${ }^{\mathrm{d}}$ \\ Sriwijaya University, Palembang, Indonesia \\ a https://orcid.org/0000-0002-9773-6035; ${ }^{b}$ https://orcid.org/0000-0002-3260-3266; \\ ${ }^{c}$ https://orcid.org/0000-00018716-3037; ${ }^{d}$ https://orcid.org/0000-0003-2966-3943
}

\begin{abstract}
The study aims to determine the Effect of growth opportunity, corporate tax, and profitability on the value of firm through the capital structure as an intervening variable at manufacturing companies in Indonesia Stock Exchange. The sample consists of 32 manufacturing sector companies listed in Indonesia Stock Exchange within 2013-2017. The study results show that growth opportunity and corporate tax have a positive effect on the structure of capital, in contrast to profitability, which affects negatively. Meanwhile, capital structure and profitability have a positive Effect on firm value. On the other hand, growth opportunity and corporate tax have no bearing on company value. Yet, capital structure does not mediate between growth opportunity and corporate tax to the value of firm. Nevertheless capital structure mediates the Effect of profitability on the value of firm.
\end{abstract}

Keywords: growth opportunity; corporate tax; profitability; value of firm and capital structure

For citation: Amarudin, Adam M., Hamdan U., Hanafi A. Effect of Growth Opportunity, Corporate Tax, and Profitability toward Value of Firm through Capital Structure (Listed Manufacturing Companies of Indonesia). Finance: Theory and Practice. 2019;23(5):18-29. DOI: 10.26794/2587-5671-2019-23-5-18-29

0530P

\section{Влияние возможностей роста, корпоративного налога и рентабельности на стоимость фирмы через структуру капитала (в индонезийских производственных компаниях, котирующихся на бирже)}

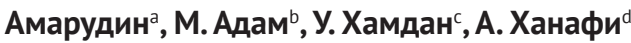 \\ Университет Шривиджая, Палембанг, Индонезия \\ a https://orcid.org/0000-0002-9773-6035; ' https://orcid.org/0000-0002-3260-3266; \\ c https://orcid.org/0000-0001-8716-3037; ${ }^{\mathrm{d}}$ https://orcid.org/0000-0003-2966-3943
}

\section{АННОТАЦИЯ}

Цель исследования - определить влияние возможности роста, корпоративного налога и прибыльности на стоимость фирмы через структуру капитала как промежуточную переменную в производственных компаниях Индонезийской фондовой биржи. Выборка состоит из 32 компаний производственного сектора, котирующихся на Индонезийской фондовой бирже в течение 2013-2017 гг. Результаты исследования показывают, что возможность роста и корпоративный налог положительно влияют на структуру капитала в отличие от прибыльности, которая оказывает отрицательное воздействие. Между тем, структура капитала и прибыльность работают на повышение стоимости фирмы. С другой стороны, возможности роста и корпоративный налог не сказываются на стоимости компании. Структура капитала не является посредником между возможностями роста и корпоративным налогом, тем не менее она опосредует влияние прибыльности на стоимость фирмы.

Ключевые слова: возможность роста; корпоративный налог; рентабельность; стоимость компании и структура капитала

Для цитирования: Amarudin, Adam M., Hamdan U., Hanafi A. Effect of Growth Opportunity, Corporate Tax, and Profitability toward Value of Firm through Capital Structure (Listed Manufacturing Companies of Indonesia). Finance: Theory and Practice. 2019;23(5):18-29. DOI: 10.26794/2587-5671-2019-23-5-18-29 


\section{BACKGROUND}

One of the main objectives of the company is to increase the value of firm through increasing the prosperity of the owners or shareholders of the company (Brigham, Gapenski, \& Daves, 2006) [1]. The value of firm describes the prosperity of shareholders in the long run so that the company's goal in the long term is to maximize the value of firm. Shareholder prosperity often reflects on increasing stock market prices (Hanafi \& Halim, 2012) [2]. The higher the stock price is, the higher the prosperity of shareholders is. The management of the company has a responsibility to manage the company in order to increase The Value of Firm. Stock market prices are a reflection of every financial decision taken by management, so that the company's value is a result of the management's actions. These financial decisions include investment decisions, funding decisions and dividend policies. The management will carefully consider the decisions taken so as to lead to an increase in The Value of Firm.

The value of a company formed through indicators of stock market value is strongly influenced by investment opportunities. Investment opportunities can provide a positive signal about the company's growth in the future so that it will increase stock prices. With the increase in stock prices, The Value of Firm will increase and can provide high prosperity to investors through the return which will be obtained. The main objective of the company according to the theory of the firm is to maximize the value of the firm (Salvatore, 2005) [3]. Maximizing The Value of Firm is very essential for the company itself, because maximizing The Value of Firm also means maximizing the prosperity of shareholders which is the company's main goal.

According to (Brigham \& Houston, 2011) [4] signaling theory is an action taken by a company to provide guidance for investors about how management views the company's prospects. The Value of Firm in this study is measured using the ratio of stock market prices to the value of the book or often referred to as the price to book value (PBV). Companies that have relatively high returns on equity usually have a stock market price many times greater than the value of their books, than companies whose returns on equity are low. Companies that have higher PBVs indicate that the company's performance in the future is assessed to be more prospective by its investors.

Based on previous research there are several factors that can affect The Value of Firm, including: growth opportunity, corporate tax, tangibility, profitability and capital structure. Some of these factors have a relationship and influence on the company's value that is not consistent. Growth opportunity / company growth can be defined as an increase that occurs in the company. The higher the growth of the company is, which also means that the company's opportunity to grow is higher, the greater the funding needs are. Companies that have high growth rates are generally small companies.

Given that tax is the main source of state revenue, then in an effort to maximize tax revenues, the government applies tax rules in such a way through other tax laws and regulations. For taxpayers, tax is a burden that must be paid to the state, and can reduce the company's net income. Therefore, in order to reduce the tax burden that must be paid, many companies carry out tax management (tax management), namely a comprehensive effort by the tax manager (Tax Manager) in a company or organization so that matters relating to taxation of the company or the organization can be managed properly, efficiently, and economically, so as to give maximum contribution to the company (Pohan, 2013) [5].

Profitability ratio is the ability of the company to obtain profits in relation to sales, total assets and own capital (Sartono, 2014) [6]. In this study profitability ratios are measured by return on assets (ROA). ROA is a ratio that shows the company's ability to generate net income to return equity to shareholders. ROA is a comparison ratio between net income after tax to total assets. The reason for using the ROA variable in this study is because it has many advantages. One of them is to be able to measure the efficiency of overall capital use, which is sensitive to every thing that affects the state of the company.

According to (Fahmi, 2012) [7], the capital structure aims to integrate the sources of permanent funds which are then used by companies in ways that are expected to be able to maximize The Value of Firm. Declining capital structure can cause changes in The Value of Firm. In accordance with the pecking order theory, companies with large profit levels will use internal funds first before using debt (Anjarwati, Chabachib, \& $P, 2015)$ [8]. In this study capital structure is calculated by the ratio of debt to equity ratio (DER), which is a ratio that compares the total debt held by the company with the total capital invested by the company for the survival of the company.

In this study, the shares of manufacturing companies were selected that are listed on the Stock Exchange Indoneia (BEI), these agencies provide the infrastructure to support the implementation of trade Effect an orderly, fair, and efficient and easily accessible to all stakeholders (stakeholders). The reason why the author chose the object of the research in manufacturing companies is because the manufacturing sector consists of various industrial sub-sectors. This reflects the reaction of the capital market as a whole, besides, manufacturing companies also have the highest number of companies on the 
Indonesia Stock Exchange. Manufacturing companies also dominate the market when compared to other companies listed on the IDX.

\section{THEORETICAL FRAMEWORK Agency Theory}

Agency theory (agency theory) is the basis of the theory underlying the company's business practices. Agency theory was put forward by (Jensen \& Meckling, 1976) [9]. This theory was developed in order to understand and solve problems that arise when there is incomplete information while making a contract (engagement). The relationship between the principal and the agent can lead to information asymmetry. Information asymmetry is a condition where there is an imbalance in information acquisition between management as an information provider (preparer) with the shareholders and stakeholders in general as users of information (users).

\section{Pecking Order Theory}

Pecking Order Theory is a theory that prioritizes funding sources from within. According to (Kartika A., 2016) [10], in brief this theory states that companies like Internal Financing (funding from the results of the company's operations in the form of retained earnings). If External Financing is needed, the company will issue the safest securities first, that is, starting with the issuance of bonds, then followed by securities characterized by options (such as convertible bonds), and finally, if this is still insufficient, new shares are issued.

\section{Growth Opportunity}

Growth opportunity is also called the opportunity of a company to grow in the future. Growth opportunity is an indicator of the extent to which a company's earnings per share increases as debt increases (Brigham E.F., Houston J.F., 2011) [4]. Companies with high growth rates will try to increase their fixed assets so that they need more funds in the future, but still have to be able to maintain the level of profit. As a result, retained earnings will increase and the company tends to owe more to maintain its debt ratio.

\section{Corporate Tax}

For taxpayers, tax is a burden that must be paid to the state, and can reduce the company's net income. Therefore, in order to reduce the tax burden that must be paid, many companies carry out tax management (tax management), which is a comprehensive effort by tax managers in a company or organization so that matters related to taxation from the company or the organization can be managed properly, efficiently, and economically, so that it gives maximum contribution to the company (Bringham E.F., Houston J.F., 2011) [4].

\section{Profitability}

Company's Profitability is one of the bases for assessing the condition of a company, for this reason an analytical tool is needed to assess it. The analytical tool in question is financial ratios. Profitability ratios measure management Effectiveness based on returns obtained from sales and investments. Profitability also has an important meaning in an effort to maintain its survival in the long term, because profitability shows whether the business entity will always try to increase its profitability, because the higher the level of profitability of a business entity is, the survival of the business entity will be more secure (Hermuningrum Sri., 2012) [11].

\section{Capital Structure}

Capital consists of equity (retained earnings and funds obtained from the sale of shares) and debt (loan funds). Corporate profit costs reflect opportunity costs (Opportunity cost); returns that can be obtained by shareholders if they maximize the value of dividends and invest the funds themselves. The company's new equity costs (issuing new shares) also reflect opportunity costs: returns obtained by new capital holders if they invest their funds in other forms, not in the company's shares. This cost is higher than the cost of retained earnings because it also covers the expenses associated with selling new shares (floating costs) (Madura J., 2011) [12].

\section{Value of Firm}

Value is a certain condition that has been achieved by a company as a picture of public trust in the company. Increasing The Value of Firm is an achievement in accordance with the wishes of its owners, because with the increase in The Value of Firm, the welfare of the owners will also increase, and this is the duty of the manager as an agent who has been entrusted by the company to run his company (Bringham E.F., Houston J.F., 2011) [4].

According to (Jansen, 2001) [13], to maximize the value of a company not only the value of equity is considered, but financial resources such as debt and preferred stock. Company value is the fair value of the company that describes the perception of investors towards certain issuers, so that company value is the perception of investors that is always associated with stock prices. Company value can be seen from the value of the shares of the company concerned. The Value of Firm is also in terms of management where The Value of Firm now depends on the value of the manager. Value-based management is also a process of maximizing company value based on continuous calculations (Harjito, 2012) [14]. 


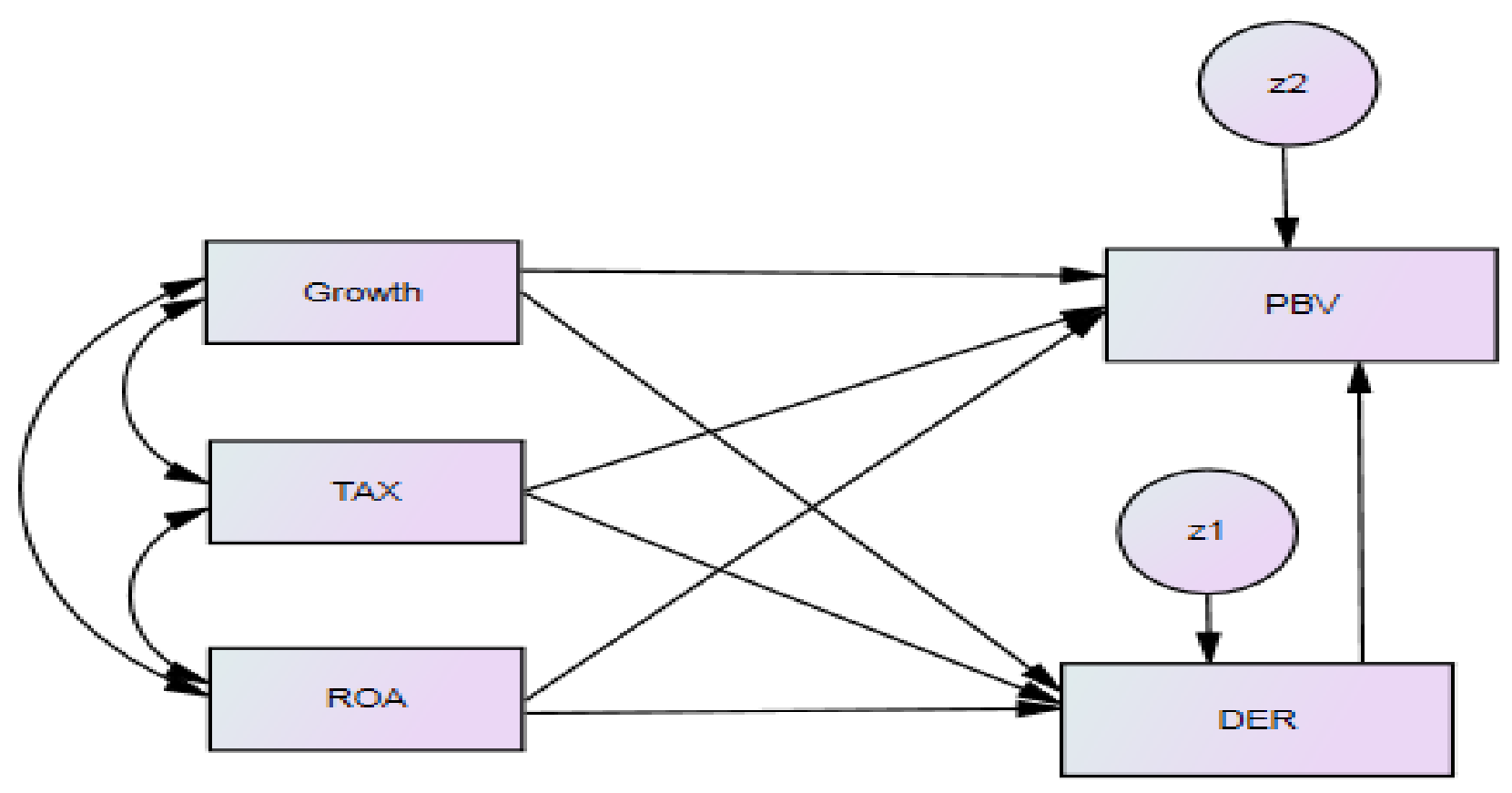

Fig. 1. Path chart diagram model

Source: Compiled by the authors.

\section{ANALYSIS AND DISCUSSION RESULTS \\ Path Analysis}

In this study, the Effect of growth opportunity, corporate tax, and profitability on firm value with capital structure as variables intervening will be analyzed using path analysis. Based on the objectives and hypotheses built in this study, the form of path diagrams to be estimated is as follows (Fig. 1).

Stages in path analysis include test path assumption path analysis, goodness of fit model test path diagram and path significance test.

\section{Prerequisite Test Path Analysis Prerequisite}

Tests in path analysis include normality and multicollinearity tests.

\section{Normality Test}

The value of cr Univariate all indicators and the value of cr multivariate in this study has been smaller \pm 2.58 so that it can be assumed that the data after elimination of outliers have not met the assumption of normality.

\section{Multicollinearity Test}

Obtained value covariance matrix determinant of sample of 0.002 because this value exceeds 0.002 , it can be stated that there is no multicollinearity in the model. The results of this test are also supported by the absence of a correlation coefficient between latent variables that exceed 0.9.

\section{Goodness of Fit Model Test}

The structural model is stated to have fulfilled the Goodness of fit model if the model has fulfilled one of the assumptions contained in the table above. According to Haryono (2017) [15], if there are one or two criteria goodness-of-fit that have met, then it can be said that the model is built well.

Based on Fig. 2, a summary of the results of the obtained goodness of fit model is as follows (Tabl. 1).

Based on Table 1, the results show that the SEM model has met all the criteria of the Goodness of fit model. The probability value of the analysis results has also exceeded 0.05 which indicates that the covariance matrix sample has similarities with the estimated population covariance matrix so that the results of the analysis are able to describe the actual population conditions. Thus the research model is feasible to be used to test the research hypothesis.

\section{Path Coefficient Significance Test}

The significance test of the path coefficient is used to test the Effect of growth opportunity, corporate tax and profitability on firm value with capital structure as a variable intervening. The results of this significance test will then be used to test the research hypothesis.

Besides being able to determine the significance of the influence of each exogenous variable on endogenous variables, the results of path analysis can also predict the contribution of all exogenous variables to endogenous variables. The contribution can be seen 

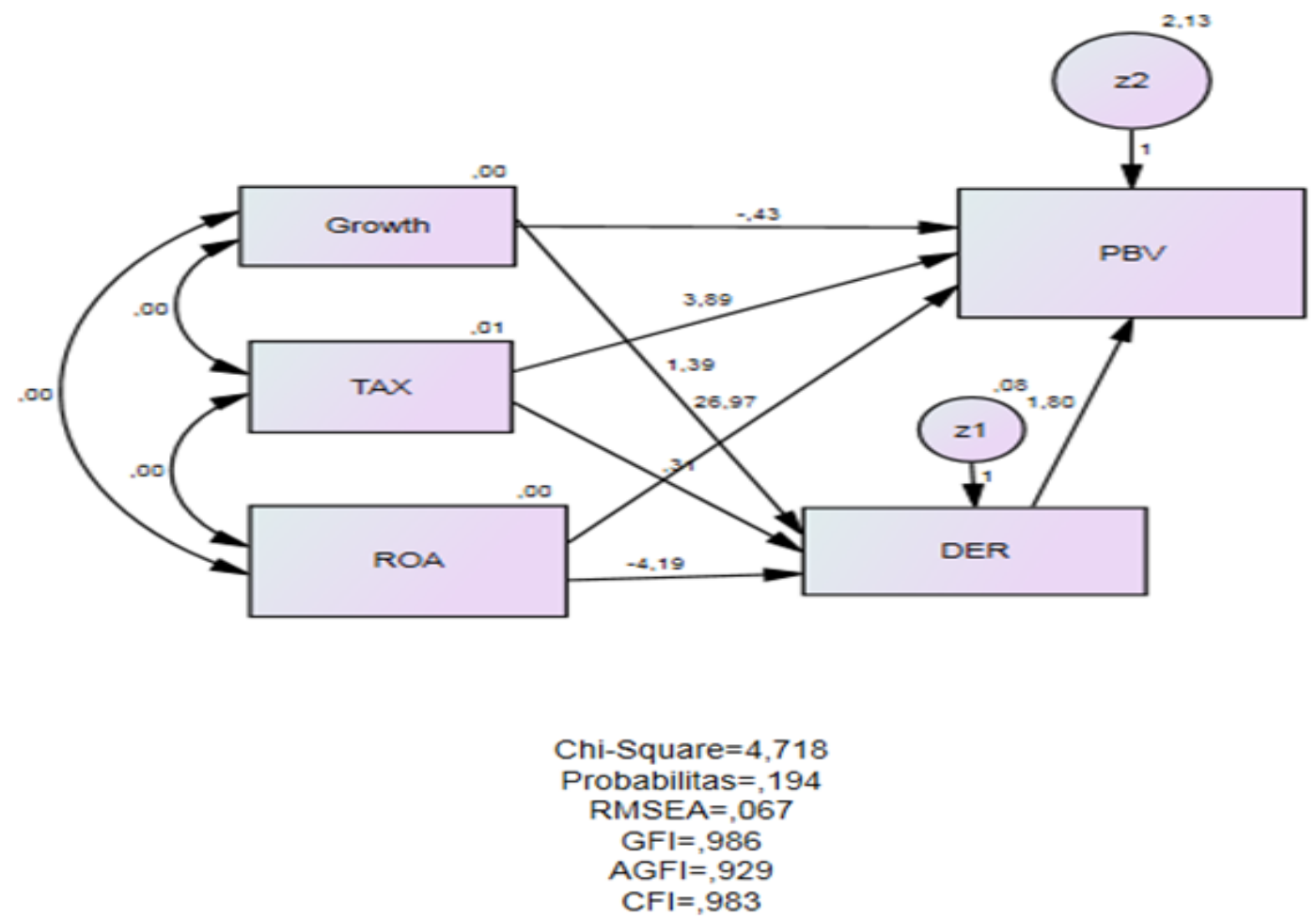

\section{Fig. 2. Goodness of fit model test results}

Source: Compiled by the authors.

Goodness of fit model test results

\begin{tabular}{|c|c|c|c|c|}
\hline No & Goodness of fit index & Cut off value (reference) & Value on model & Description \\
\hline 1 & Chi - Square & $<7815$ & 4718 & Fit \\
\hline 2 & Probability & $>0.05$ & 0194 & Fit \\
\hline 3 & GFI & $>0.9$ & 0.986 & Fit \\
\hline 4 & AGFI & $>0.9$ & 0.929 & Fit \\
\hline 5 & CFI & $>0.95$ & 0.986 & Fit \\
\hline 6 & RMSEA & $<0.08$ & 0.067 & Fit \\
\hline
\end{tabular}

Source: Data processed by the researchers.

from the value Squared Multiplier size of each endogenous variable.

Based on Table 3, the value of the squared multiple correlation DER variable is 0.318 , this indicates that the contribution of the GROWTH, TAX and ROA variables given to the DER is $31.8 \%$, and the value of the squared multiple correlation variable PBV is 0.372 , indicating that the contribution given by the GROWTH, TAX and ROA variables to the $\mathrm{DER}$ variable is $37.2 \%$.

\section{Direct, Indirect and Total Influence Test}

The results of direct, indirect and total influence by AMOS 22 are as follows:
Contributions to direct influence and indirect Effects of growth against PBV is as follows (Tabl 4).

From Table 4 it can be seen that, the value of the direct Effect of growth on the PBV is equal to 0.068 , while the indirect Effect of growth on the PBV through DER is 0,044, the total overall Effect is 112. Since the direct Effect of growth on the PBV is greater than the Effect of Indirect growth of PBV through DER, it can be concluded that DER in this study is not a variable intervening.

The direct influence and indirect influence of TAX on PBV are as follows (Tabl. 5).

From Table 5 it can be seen that the direct Effect of TAX on PBV is 0.105 , while the indirect Effect of size 


\section{Significance test results}

\begin{tabular}{|c|c|c|c|c|l|}
\hline & & & Effect Value & Coefficient Line & \multicolumn{1}{|c|}{ Description } \\
\hline DER & $<-$ & TAX & 013 & .185 & Influential (+) significantly \\
\hline DER & $<-$ & ROA & $* * *$ & -.498 & Influential (-) significantly \\
\hline DER & $<-$ & Growth & 011 & .188 & Influential (+) significantly \\
\hline PBV & $<-$ & Growth & 349 & .068 & No Effect \\
\hline PBV & $<-$ & TAX & 153 & .105 & No Effect \\
\hline PBV & $<-$ & ROA & $* * *$ & 665 & Influential (+) significantly \\
\hline PBV & $<-$ & DER & .006 & .235 & Significant (+) Effect \\
\hline
\end{tabular}

Source: Researcher's data.

Squared multiple correlation

\begin{tabular}{|c|c|}
\hline & Estimate \\
\hline DER value & .318 \\
\hline PBV & .372 \\
\hline
\end{tabular}

Source: Researcher's data.

Effect of direct and indirect Growth of the PBV

\begin{tabular}{|c|c|}
\hline Description & Value \\
\hline Direct Effect (direct Effect), & 068 \\
\hline Indirect Effect Growth to PBV through DER (indirect Effect) & 044 \\
\hline Total Effect (total Effect) & 112 \\
\hline
\end{tabular}

Source: Data processed by the researchers.

on PBV through DER is 0.105 , the total overall Effect is 0.149. Because of the direct influence of TAX against PBV greater than the indirect Effect of TAX on PBV through DER, it can be concluded that DER in this study is not a variable intervening.

Direct influence and indirect influence of ROA against PBV is as follows (Tabl. 6).

From Table 6 it can be seen that the direct Effect of ROA on PBV is -0.117 , while the indirect Effect of ROA on PBV through DER is 0.665 , the total overall Effect is 0.548. Although the direct Effect of ROA on PBV is smaller than the indirect Effect of ROA on PBV through DER, it can be concluded that DER in this study is a variable intervening. DER is full mediation because through DER, ROA can affect PBV.

\section{DISCUSSION}

Growth opportunity in this study has a positive Effect on capital structure. The results of this study are in accordance with the Signaling Theory which states that companies that have large assets have greater access to funding sources or loan funds from creditors, because creditors believe in the amount of assets owned can be used as collateral to lend funds to the company, and high sales indicate that the company is developing, so it has good prospects for the long term. The study results support the research conducted by (Febriyani and Srimindarti, 2010) [16] and (Seftianne and Handayani, 2011) [17] which state that growth opportunity influences capital structure. The study results do not correspond to the results of the study by Mai (2006) [18] 


\section{Direct and indirect Effects of TAX on PBV}

\begin{tabular}{|l|c|}
\hline \multicolumn{1}{|c|}{ Description of } & Value of \\
\hline (direct Effect) & .106 \\
\hline Indirect Effects of TAX to PBV through DER(indirect Effect) & .105 \\
\hline Total Effect (total Effect) & 149 \\
\hline
\end{tabular}

Source: Researcher's data.

Effect of direct and indirect ROA on PBV

\begin{tabular}{|l|c|}
\hline \multicolumn{1}{|c|}{ Description } & Value \\
\hline direct Effect (direct Effect) & -.117 \\
\hline indirect Effect ROA to PBV through DER (indirect Effect) & .665 \\
\hline Total Effect (total Effect) & .548 \\
\hline
\end{tabular}

Source: Researcher's data.

which states that growth opportunity does not affect the capital structure.

Growth opportunity in this study does not affect The Value of Firm, the results of this study do not correspond to the proposed hypothesis, which states that growth opportunity has a positive Effect on firm value, meaning that the high and low growth of the company is not influenced by the high value of the company in the same direction. The results of this study are not in line with the results of the research conducted by Dewi (2014) [19], who found that the company's growth had a positive and significant Effect on firm value.

The results showed that the direct Effect of growth on PBV was greater than the indirect Effect of growth on PBV through DER, so it can be concluded that DER in this study was not a variable intervening. These findings do not correspond to the proposed hypothesis, which states that growth opportunity has a positive Effect on firm value with a capital structure as a variable intervening. The results of this study are not in line with the trade of theory which states that an increase in the debt ratio in the capital structure will increase The Value of Firm. The policy of using debt in the company's capital structure gives a signal to the investor that the funding policy by the company affects The Value of Firm. Positive responses from investors will cause the increase in growth opportunity. A high growth opportunity will cause an increase in investment. This increase in investment means that there is also an increase in the asset structure. Growth opportunity and high asset structure will cause the increase in the use of debt in the capital structure and subsequently will affect The Value of Firm.

Corporate tax in this study has a positive Effect on capital structure. The results of this study indicate that the higher corporate tax is, the higher the capital structure of a company is, and the lower the corporate tax is, the lower the capital structure of a company is; that is, between corporate tax and structure capital it has the same direction. These findings correspond to the hypothesis proposed, which states that corporate tax has a positive Effect on capital structure. The theory by Modigliani-Miller (MM) explains that the use of debt will be more profitable compared to self-capital. This is because the creditors in setting the interest rate of their loans adjusted to the economic conditions of a country that has a tendency to affect the ability of companies to repay loans, for example, the inflation rate. It can be concluded that it is very unlikely that creditors apply loan interest rates that are too burdensome to debtors, because it will cause problems for creditors themselves, namely the possibility of a bad debt.

The study results support the research conducted by Setiawati (2011) [20], Owolabi and Inyang (2012) [21], Rostami and Akparpour (2012) [22], and Dewi (2013) [19], in their research stating that tax has a positive and significant Effect on capital structure. Research by Anisa and Djumahir (2014) [23], Dewi and Bajra (2013) [24] states that tax has a positive significant Effect on capital structure, but the results of this study do not support the research conducted by Chaerunisa and 
Farah (2014) [25] which states that tax does not affect the capital structure.

The results of the study show that corporate tax does not affect The Value of Firm, meaning that The Value of Firm is not influenced by corporate tax. The results of this study do not correspond to the proposed hypothesis, which states that corporate tax has a positive Effect on firm value. Corporate tax does not affect The Value of Firm due to the amount of cash issued by the company for the payment of the tax burden in the long run according to the applicable corporate income tax rate. This is responded to by the market (investor) as a reason that does not affect The Value of Firm.

This study found that the direct Effect of corporate tax on firm value is greater than the indirect Effect of corporate tax on firm value through capital structure. Thus, in this study capital structure is not a variable intervening. The results of this study do not correspond to the proposed hypothesis, which states that corporate tax affects The Value of Firm with the capital structure as a variable intervening.

Capital structure shows the comparison between the amount of long-term debt and own capital. Companies that use debt in their operations will get tax savings, because taxes are calculated from operating profits after deducting interest on debt. Therefore, net income that is the right of shareholders will be greater than companies that do not use debt. Thus, The Value of Firm also becomes greater. This means that if the capital structure is larger, The Value of Firm will also increase. However, companies will not be able to use $100 \%$ debt in their capital structure. This is because the greater the debt is, the greater the financial risk of the company is. The risk in question is financial risk, namely the risk that arises because of the company's inability to pay interest and principal installments in poor economic conditions. In such conditions if the debt is greater, The Value of Firm will decrease.

Based on the results of the hypothesis, it can be explained that profitability has a negative Effect on capital structure variables. Companies that have a high ability to make profits use retained earnings (equity) as capital to finance the company's operations without external funds. According to Kartika (2016) [10], this is in line with the Pecking Order Theory. The Pecking Order Theory states that companies like internal financing (funding from the company's operating results in the form of retained earnings) and, if external financing is required, the company will first issue the safest option, namely by issuing bonds. Thus, companies with high profitability will set aside profits in retained earnings. In the case of retained earnings, the company does not require external financing, since retained earnings are used to finance the activities of the company. With retained earnings or due to equity capital, a small impact on capital structure will be of small size.

The results of this study are in line with the results of the studies by Anjarwati et al. (2015) [8], Kartika (2016) [10], Kontesa (2015) [26], Paminto, Setyadi, \& Sinaga (2016) [27], Thomas, Chenuos \& Biwott (2014) [28], Arini (2012) [29], Damayanti (2013) [30],, Natalia (2015) [31], Rita Puji Astuti (2013) [32], Safitri (2014) [33], Setiawati (2010) [34] showing that profitability has a significant negative Effect on capital structure. The study results also correspond to the statement by Hamidy (2014) [35] and Lusangaji (2011) [36] that companies with high profitability will have more internal funds (retained earnings) than companies with low profitability. With large retained earnings, companies will prefer to use retained earnings before using debt.

The results of the study show that profitability has an Effect on company value. The findings are in line with the proposed hypothesis which states that profitability has a positive Effect on firm value. The high and low profitability of the company affects the high and low value of the company, the influence is in the same direction. The higher the profitability of the company is, the higher The Value of Firm is, and vice versa. Profitability is the company's ability to generate profits. If the company generates high profits, it indicates that the company's performance is good and has good prospects for the long term, so it can attract investors to buy the company's shares. With the number of investors who will buy these shares, the demand for shares will be high, it will increase stock prices.

High stock prices reflect high corporate value and high profitability reflects the company's ability to generate high returns for shareholders. With a high profitability ratio owned by a company will attract investors to invest their capital. In addition, with a good profitability ratio, investors will respond positively. Positive responses from investors will increase stock prices to further increase company value. This is consistent with the concept of the signaling theory. The theory claims that profitability will be a signal from the management that describes the company's prospects on the basis of the formed level of profitability and directly affects the value of the company, as can be seen from the share of the price in the market.

The study results are consistent with the results of the studies by Anjarwati et al. (2015) [8], Dewi \& Wirajaya (2013) [19], Kontesa (2015) [26], Paminto et al., (2016) [27], Hamidy (2014) [36], Kodongo et al. (2014) [37], Sucuahi \& Cambarihan (2016) [38], Agustia (2010) [39], Alfredo Mahendra DJ (2011) [40], Bukit (2012) [41], Kusumajaya (2011) [42], Languju et al. (2016) [43], Nurhayati (2013) [44], Prisilia (2012) [45], Suffah \& Riduwan (2016) [46], Wulandari (2013) [47]. These studies show that profitability has a significant positive Effect on firm value. 
Based on the DER analysis in this study, it is an intermediate variable, this result due to the direct influence of ROA on PBV is less than the indirect effect of ROA on PBV, it can be concluded that the DER variable can mediate the effect of ROA on PBV. Based on these results, which argue that the capital structure can be an intermediary between profitability and the value of the company, contrary to the Pecking Order theory, which states that the higher the profitability, the more profit will be saved, so that the capital structure will be low. This means that if the company has a large level of profit, it will have a greater internal source of financing. This will influence the decision on the capital structure or financing of the company, namely in financing its business activities, such as developing products or needs through investment costs that allow companies to use their own capital, namely from domestic companies, for example, in the form of retained earnings as profits generated by the company rather than using external funds.

In this study, capital structure can mediate the Effect of profitability on firm value. This can happen if internal funding sources are no longer sufficient. For example, if a company expands, which requires a large amount of funds to stimulate a future increase in profits, the company can use as an alternative a source of external funds, namely in the form of debt received from external parties. That is, both internal and external funding sources are used to increase company profits. If not considered properly, their use will have a negative Effect on The Value of Firm. These results are consistent with the research conducted by Chen and Chen (2011) [48] stating that profitability has a significant Effect on The Value of Firm with the capital structure as an intervening variable.

This study shows that the capital structure has a positive Effect on firm value. These findings are consistent with the proposed hypothesis stating that the capital structure has a positive Effect on firm value. Companies must be able to determine the amount of debt, because the existence of debt to a certain extent will be able to increase The Value of Firm. However, if the amount of debt goes beyond a certain limit it will reduce The Value of Firm. The study results are consistent with the Trade-off theory which explains that if the position of the capital structure is below the optimal point, each addition of debt will increase The Value of Firm. The trade-off theory predicts a positive relationship with The Value of Firm. The results of this study correspond to the study results by Hermuningsih (2012) [11], Kontesa (2015) [26], Hamidy
(2014) [35], Bukit (2012) [41], Kusumajaya (2011) [42] showing that the capital structure has a positive Effect on firm value.

\section{CONCLUSION}

Some conclusions obtained from the results of this study are as follows:

1. Growth opportunity has a positive Effect on the company's capital structure, this means that the size of the company growth is able to influence the high and low capital structure of the company, the Effect is in the same direction. The higher the size of the company is, the greater the company's capital structure is, and vice versa.

2. Growth opportunity does not affect The Value of Firm. High and low growth opportunity does not affect the high and low values of the firm's capital structure. It cannot mediate the Effect of growth opportunity to company value.

3. Corporate tax has a positive Effect on the capital structure of the company. This means that the high and low corporate tax affects the high and low capital structure of the company, the Effect is unidirectional. The higher the corporate tax is, the higher the capital structure of the company is, and vice versa.

4. Corporate tax does not affect The Value of Firm. The high and low corporate tax of a company does not affect The Value of Firm.

5. Capital structure cannot mediate the Effect of corporate tax on firm value.

6. Profitability has a negative Effect on the variable capital structure of the company. High and low profitability is against the high and low capital structure of the company.

7. Profitability has a positive Effect on firm value. The high and low profitability of a company has an Effect on the high and low value of the company, the influence is in the same direction. The higher the profitability of the company is, the higher The Value of Firm is.

8. Capital structure can mediate the Effect of profitability on firm value.

9. Capital structure has a positive Effect on corporate value variables, this means that the high and low capital structure of the company has an influence on the high and low value of the company, the influence is the same. The higher the company's capital structure is, the higher The Value of Firm is.

\section{REFERENCES}

1. Brigham E.F., Daves P.R. Intermediate financial management. $9^{\text {th }}$ ed. Mason, OH: Thomson/South-Western College Publ.; 2006:145-154.

2. Hanafi M., Halim A. Analysis of financial statements. Yogyakarta: UPP STIM YKPN; 2012:34-37. (In Indones.). 
3. Salvatore D. International economics. Transl. from Eng. Jakarta: Erlangga; 2005:78-82. (In Indones.).

4. Bringham E.F., Houston J.F. Fundamentals of financial management. $11^{\text {th }}$ ed. Transl. from Eng. Jakarta: Salemba Empat; 2011:78-85. (In Indones.).

5. Pohan C.A. Tax management: Tax and business planning strategies. Jakarta: PT. Gramedia Pustaka Utama; 2013:123-125. (In Indones.).

6. Sartono A. International financial management. Yogyakarta: BPFE; 2014:148-154. (In Indones.).

7. Fahmi I. Risk management: Theories, cases and solutions. Bandung: Alfabeta; 2012:214-245. (In Indones.).

8. Anjarwati K., Chabachib M., Demi I.R.P. The effect of profitability, size, and liquidity on the value of manufacturing companies in Indonesia with capital structure as intervening variables. Diponegoro University Management Masters Program. 2015:14-19. URL: http://eprints.undip.ac.id/51133/1/jurnal_KENTI.pdf (In Indones.).

9. Jensen M.C., Meckling W.H. Theory of the firm: Managerial behavior, agency costs, and ownership structure. Journal of Financial Economics. 1976;3(4):305-360. DOI: 10.1016/0304-405X(76)90026-X

10. Kartika A. Effect of profitability, asset structure, growth in sales and firm size on the capital structure of manufacturing companies in the Indonesia Stock Exchange. INFOKAM. 2016;12(1):86-98. URL: http://id.portalgaruda.org/index.php?ref=browse \&mod=viewarticle\&article=515163 (In Indones.).

11. Hermuningsih Sri. Effect of profitability, growth opportunity, capital structure on the value of companies in public companies in Indonesia. Buletin Ekonomi Moneter dan Perbankan = Bulletin of Monetary Economics and Banking. 2013;16(2):127-148. DOI: 10.21098/bemp.v16i2.27 (In Indones.).

12. Madura J. International corporate finance. Transl. from Eng. Jakarta: Salemba Empat; 2011:232-236. (In Indones.).

13. Jensen M.C. Value maximization, stakeholder theory, and the corporate objective function. Journal of Applied Corporate Finance. 2001;14(3):8-21. DOI: 10.1111/j.1745-6622.2001.tb00434.x

14. Harjito A., Martono A. Financial management. $2^{\text {nd }}$ ed. Yogyakarta: Ekonisia; 2012:76-84. (In Indones.).

15. Haryono S. SEM method for management research: AMOS, LISREL \& PLS. Jakarta: Pt. Luxima Metro Media; 2017:134-148. (In Indones.).

16. Febriyani N., Srimindarti C. Factors affecting capital structure in LQ- 45 companies on the Indonesia Stock Exchange for the period 2006-2008. Dinamika Keuangan dan Perbankan = Financial and Banking Dynamics. 2010;2(2):138-159. URL: https://www.unisbank.ac.id/ojs/index.php/fe1/article/view/2086 (In Indones.).

17. Seftianne S., Handayani R. Factors affecting capital structure in public companies in the manufacturing sector. Jurnal Bisnis dan Akuntansi = Journal of Business and Accounting. 2011;13(1):39-56. DOI: https://doi.org/10.34208/ jba.v13i1.214 (In Indones.).

18. Mai M.U. Analysis of variables that affect the capital structure of LQ-45 companies on the Jakarta Stock Exchange. Tirtayasa Ekonomika. 2006;2(2):228-243. (In Indones.).

19. Dewi A.S.M., Wirajaya A. Effect of capital structure, profitability, and company size on company value. E-Jurnal Akuntansi Universitas Udayana = Accounting E-Journal of Udayana University. 2013;4(2):358-372. URL: https://ojs. unud.ac.id/index.php/Akuntansi/article/view/6233 (In Indones.).

20. Setiawati L. Advanced accounting. Jakarta: PT Bhuana Ilmu; 2011:12-15. (In Indones.).

21. Owolabi S.A., Inyang U.E. Determinants of capital structure in Nigerian firms: A theoretical review. Canadian Journal of Accounting and Finance. 2012;1(1):7-15.

22. Rostami J.M. Akbarpour Z. Study of the relationship between capital structure and tax: Evidence from Iran. International Journal of Contemporary Business Studies. 2012;3(11):35-45.

23. Anisa D., Djumahir. Structure effect capital, dividend policy, company size, share ownership managerial and profitability of company value. Study on manufacturing companies listed on the Indonesia Stock Exchange in 2011-2013. Journal of Business Economics. 2014:163-178. (In Indones.).

24. Dewi N.K.S.M., Badjra I.B. Effect of liquidity, profitability, tangibility assets, company size and taxes on capital structure. E-Jurnal Manajemen Universitas Udayana =E-Journal Management of Udayana University. 2014;3(10):3017-3033. URL: https://ojs.unud.ac.id/index.php/Manajemen/article/view/9403 (In Indones.).

25. Farah Margaretha. Determinants of debt policy in Indonesia's public company. Review of Integrative Business and Economics Research. 2014;3(2):10-16.URL: http://sibresearch.org/uploads/2/7/9/9/2799227/riber_b14-016_10-16.pdf

26. Kontesa M. Capital structure, profitability, and firm value. Whats new? Research Journal of Finance and Accounting. 2015;6(20):185-192. URL: https://www.iiste.org/Journals/index.php/RJFA/article/view/26331/26991

27. Paminto A., Setyadi D., Sinaga J. The effect of capital structure, firm growth and dividend policy on profitability and firm value of the oil palm plantation companies in Indonesia. European Journal of Business and Management. 2016;8(33):123-134. URL: https://pdfs.semanticscholar.org/8436/dc3239182b69a02b949be1df1c678f8427c0.pdf 
28. Thomas K.T., Chenuos N., Biwott G. Do profitability, firm size, and liquidity affect capital structure? Evidence from Kenyan listed firms. European Journal of Business and Management. 2014;6(28):119-123. URL: https://www. researchgate.net/publication/267097905_Do_Profitability_Firm_Size_and_Liquidity_Affect_Capital_Structure_ Evidence_from_Kenyan_Listed_Firms

29. Arini F., Harlen dro. Effect of liquidity, company size, asset structure, profitability, and sales growth on capital structure (Study of mining companies listed on the Indonesia Stock Exchange). Jurnal Ilmiah Mahasiswa FEB. 2012;2(2):24-32. (In Indones.).

30. Damayanti D. The effect of asset structure, company size, growth opportunities and profitability on capital structure study of armored companies listed on the IDX. Jurnal Perspektif Bisnis = Business Perspectives Journal . 2013;1(1):17-32. (In Indones.).

31. Natalia P. Effect of profitability, sales growth, asset structure, and business risk on capital structure at Kompas 100 issuers (Non-banking). Jurnal Manajemen = Management Journal. 2015;14(2):141-164. URL: https://media.neliti. com/media/publications/114942-ID-pengaruh-profitabilitas-pertumbuhan-penj.pdf (In Indones.).

32. Rita Puji Astuti. The effect of profitability, size, growth opportunity, liquidity and asset structure on the bank's capital structure (Study of banking companies on the Indonesia Stock Exchange in 2009-2013). Jurnal Ilmiah Mahasiswa S 1 Akuntansi Universitas Pandanaran. 2013;1(1):1-19. URL: https://jurnal.unpand.ac.id/index.php/ AKS/article/view/199/195 (In Indones.).

33. Safitri U.K. Effect of profitability and size on company values with capital structure as intervening variables (Empirical study of manufacturing companies listed on the Indonesia Stock Exchange 2011-2014). Department of Management, Faculty of Economics and Business, University of Muhammadiyah Yogyakarta; 2014:1-7. URL: http://repository.umy.ac.id/bitstream/handle/123456789/8696/NASKAH\%20PUBLIKASI. pdf?sequence $=1$ \&isAllowed $=y$ (In Indones.).

34. Diana A., Setiawati L. Indonesian taxation: Concepts, applications and practical guides. $3^{\text {rd }}$ ed. Jakarta: Penerbit Andi; 2010:16-24. (In Indones.).

35. Hamidy R.R., Wiksuana I.G.B., Artini L. G.S. Effect of capital structures on firm value with profitability as intervening variables in property and real estate companies on the Indonesia Stock Exchange. E-Jurnal Ekonomi dan Bisnis Universitas Udayana. 2015;4(10):665-682. URL: https://ojs.unud.ac.id/index.php/EEB/article/ view/10237/12042 (In Indones.).

36. Lusangaji. D. Effect of company size, asset structure, company growth, and profitability to capital structure (Study of food and beverage companies listed on the IDX). Jurnal Ilmiah Mahasiswa FEB. 2011;1(2):48-56. (In Indones.).

37. Kodongo O., Mokoaleli-Mokoteli T., Maina L. Capital structure, profitability, and firm value: Panel evidence of listed firms in Kenya. MPRA Paper. 2014;(57116):12-24. URL: https://mpra.ub.uni-muenchen.de/57116/1/MPRA_ paper_57116.pdf

38. Sucuahi W., Cambarihan J.M. Influence of profitability to the firm value of diversified companies in the Philippines. Accounting and Finance Research. 2016;5(2):149-153. DOI: 10.5430/afr.v5n2p149

39. Agustia D. Pengaruh Faktor Good Corporate Governance, Free Cash Flow, dan Leverage Terhadap Manajemen Laba. Jurnal Akuntansi dan Keuangan = Journal of Accounting and Finance. 2013;15(1):27-42. DOI: 10.9744/jak.15.1.27-42 (In Indones.).

40. Mahendra Dj A. Effect of financial performance on company value (Dividend policy as a moderating variable) in the company manufacturing on the IDX. 2011:67-78. (In Indones.).

41. Bukit R.B. Effect of capital structure on firm values through profitability: Analysis of panel data of manufacturing companies on the Indonesia Stock Exchange. Jurnal Keuangan \& Bisnis Program Studi Magister Manajemen Sekolah Tinggi Ilmu Ekonomi Harapan. 2012:4(3):205-218. (In Indones.).

42. Kusumajaya D. Effects of capital structure and growth of company on the profitability and value of manufacturing companies on the Indonesia Stock Exchange. Magister Program, Udayana University. 2011:3642. URL: https://docplayer.info/30215886-Pengaruh-struktur-modal-dan-pertumbuhan-perusahaan-terhadapprofitabilitas-dan-nilai-perusahaan-pada-perusahaan-manufaktur-di-bursa-efek-indonesia.html (In Indones.).

43. Languju O., Mangantar M., Tasik H.H.D. Effects of return on equity, company size, price earning ratio and capital structure on the value of property and real estate companies listed on the Indonesia Stock Exchange. Jurnal Berkala Ilmiah Efisiensi. 2016;16(2):387-398. URL: https://ejournal.unsrat.ac.id/index.php/jbie/article/ view/12530/12102 (In Indones.).

44. Nurhayati M. Profitability, liquidity and company size influence on dividend policy and company value in nonservice sectors. Jurnal Keuangan \& Bisnis = Journal of Finance and Business. 2013;5(2):144-153. URL: https://www. researchgate.net/publication/326551702_PROFITABILITAS_LIKUIDITAS_DAN_UKURAN_PER (In Indones.). 
45. Prisilia I. The effect of capital structure, profitability, liquidity, and managerial ownership on company value in consumer goods companies listed on the Stock Exchange in the 2008-2012 period. Jurnal Online Mahasiswa Fakultas Ekonomi Universitas Riau. 2014;(Oct.):24-37. URL: https://media.neliti.com/media/publications/33610ID-pengaruh-struktur-modal-profitabilitas-likuiditas-dan-kepemilikan-manajerial-ter.pdf (In Indones.).

46. Suffah R., Riduwan A. The effect of profitability, leverage, company size and dividend policy on firm value. Jurnal Ilmu dan Riset Akuntansi = Journal of Science and Accounting Research. 2016;5(2):1-17. (In Indones.).

47. Wulandari D.R. Effect of profitability, operating leverage, liquidity on firm value with capital structure as an intervening variable. Accounting Analysis Journal. 2013;2(4):455-463. (In Indones.). DOI: 10.15294/aaj.v2i4.4172

48. Chen L.-J., Chen S.-Y. The influence of profitability on firm value with capital structure as the mediator and firm size and industry as moderators. Investment Management and Financial Innovations. 2011;8(3):121-129. DOI: $10.1201 / \mathrm{b} 11108-9$

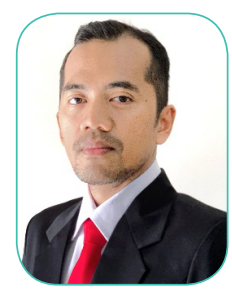

Amarudin - Graduate student, Faculty of Economics, Sriwijaya University, Palembang, Indonesia Амарудин - аспирант экономического факультета, Университет Шривиджая, Палембанг, Индонезия

amarudin.unsri@gmail.com

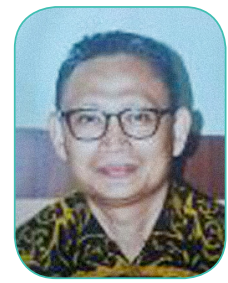

Mohamad Adam - Professor, Faculty of Economics, Sriwijaya University, Palembang, Indonesia Мохамад Адам - профессор экономического факультета, Университет Шривиджая, Палембанг, Индонезия mr_adam2406@yahoo.com

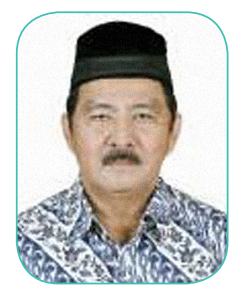

Umar Hamdan - Lecturer, Faculty of Economics, Sriwijaya University, Palembang, Indonesia Умар Хамдан - преподаватель экономического факультета, Университет Шривиджая, Палембанг, Индонезия

umarhamdanunsri@yahoo.com

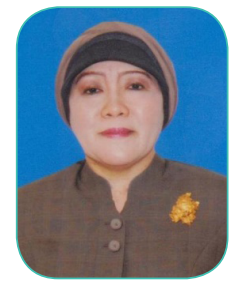

Agustina Hanafi - Master in Management Sciences, Lecturer, Faculty of Economics, Sriwijaya University, Palembang, Indonesia

Агустина Ханафи - преподаватель экономического факультета, магистр наук управления, Университет Шривиджая, Палембанг, Индонезия

tinahanafi@ymail.com

\section{Authors' declared contribution:}

Amarudin - Theoretical part, methodology, research data collection, analysis of data processing results. Mohamad Adam - Modeling in path analysis and conclusion of research results.

Umar Hamdan - Discussion of research results and general conclusions of research results.

Agustina Hanafi - Discussion of research results.

The article was submitted on 05.08.2019; revised on 19.08.2019 and accepted for publication on 20.08.2019.

The authors read and approved the final version of the manuscript.

Статья поступила в редакцию: 05.08.2019; после рецензирования: 19.08.2019; принята к публикации 20.08.2019. Авторы прочитали и одобрили окончательный вариант рукописи. 